\title{
Presepsin as a predictor of severe sepsis in urinary tract infection
}

\section{Yoshitaka Sekine ( $\nabla$ ysekine@gunma-u.ac.jp )}

Gunma University Graduate School of Medicine

Kazuhiko Kotani

Jichi Medical University

Daisuke Oka

Gunma University Graduate School of Medicine Hiroshi Nakayama

Gunma University Graduate School of Medicine Yoshiyuki Miyazawa

Gunma University Graduate School of Medicine Takahiro Syuto

Gunma University Graduate School of Medicine

\section{Seiji Arai}

Gunma University Graduate School of Medicine

\section{Masashi Nomura}

Gunma University Graduate School of Medicine

\section{Hidekazu Koike}

Gunma University Graduate School of Medicine

\section{Hiroshi Matsui}

Gunma University Graduate School of Medicine

\section{Yasuhiro Shibata}

Gunma University Graduate School of Medicine

\section{Masami Murakami}

Gunma University Graduate School of Medicine

\section{Kazuhiro Suzuki}

Gunma University Graduate School of Medicine

\section{Research Article}

Keywords: presepsin, urinary tract infection, sepsis, procalcitonin

Posted Date: March 13th, 2021 
DOl: https://doi.org/10.21203/rs.3.rs-284985/v1

License: (c) (1) This work is licensed under a Creative Commons Attribution 4.0 International License. Read Full License 


\section{Abstract}

Background Recently, presepsin is reported to be a biomarker for early diagnosis of sepsis and evaluation of prognosis in septic patients, but there are few reports about urinary-tract infections. The objective of this study is to evaluate whether presepsin is a recent marker for detecting severe sepsis, and whether it can predict the therapeutic course in UTI when compared with procalcitonin (PCT) and C-reactive protein (CRP), already used markers.

Methods From April 2014 to December 2016, a total of 50 patients, who were admitted into Gunma university hospital with urinary-tract infections, were enrolled in this study. Vital signs, presepsin, PCT, CRP, white blood cell (WBC), causative diseases of urinary-tract infections and other data were evaluated at the enrollment, third and fifth days. The patients were divided into two groups; with $(n=11)$ or without $(n=39)$ septic shock at the enrollment day, and with $(n=7)$ or without $(n=43)$ sepsis at the fifth day, respectively. Presepsin was evaluated for systemic inflammatory response syndrome (SIRS) or septic shock.

Results Concerning the enrollment day, there was no significant difference of presepsin between SIRS and non-SIRS groups $(p=0.276)$. The median presepsin $(\mathrm{pg} / \mathrm{mL})$ was significantly higher in the septic shock group ( $p<0.001)$. Multivariate logistic regression analysis showed presepsin $(\geqq 500 \mathrm{pg} / \mathrm{ml}$ ) was an independent risk factor associated with septic shock ( $p=0.007)$. ROC curve for diagnosing septic shock indicated an area under the curve (AUC) at 0.881 for presepsin (vs. $0.690,0.583$ and 0.527 for PCT, CRP and WBC, respectively). Concerning the 5th day after admission, the median presepsin of the enrollment day was significantly higher in SIRS groups than non-SIRS groups $(p=0.006)$. On the other hand, PCT $(\geq 2$ $\mathrm{ng} / \mathrm{ml}$ ) of the enrollment day was an independent risk factor associated with SIRS. ROC curve for diagnosing sepsis at the fifth day indicated an AUC at 0.837 for PCT (vs. 0.817, 0.811 and 0.802 for presepsin, CRP and WBC, respectively).

Conclusions This study shows that presepsin may be a good marker for diagnosis of severe patients who need vasopressor therapy at the data of admission, and PCT may be a good marker for predicting hardto-treat cases in UTI.

\section{Introduction}

Urinary tract infections (UTI) are common, and sometimes progresses to sepsis or septic shock, which can be lethal. Mortality from severe sepsis and septic shock is reported to be between $20-50 \%[1,2]$, and the ratio of UTI in all-cause of severe sepsis and septic shock is 9-31\% [2]. Therefore, the diagnosis and severity of sepsis or septic shock are important at the beginning of treatment in UTI.

Clinically, C-reactive protein (CRP) and procalcitonin (PCT) are used as markers of disease severity in UTI. However, both CRP and PCT have some limitations. The response time after bacterial infections is delayed (CRP; 6hr, PCT; 2-3hr), the trigger for production is not living bacteria (CRP; cytokine, PCT; endotoxin and cytokine), and the serum half-time is long (CRP; 4-6hr, PCT; 20-24hr) [3,4]. Therefore, a new 
biomarker of bacterial infection, which reflects the clinical condition at the time of measurement is required.

Presepsin is a $13 \mathrm{KDa}$ fragment of the N-terminal of soluble CD14 [5]. Granulated leukocyte phagocytose both bacteria and CD14 and expel presepsin into the blood after enzymatic digestion of bacteria within two hours $[5,6]$. Recently, presepsin has been reported to have a high sensitivity for detecting sepsis and to be a biomarker for early diagnosis of sepsis [7]. Moreover, elevated presepsin levels on day 1 can evaluate the prognosis of septic patients in intensive-care unit $[8,9]$. However, there are few reports on the use of presepsin in UTI.

The objective of this study is to evaluate whether presepsin is a useful marker for detecting sepsis or severe sepsis, and whether it can predict the therapeutic courses in UTI compared with other markers, such as PCT and CRP.

\section{Materials And Methods}

\section{Patients}

We performed a prospective observational study. From April 2014 to December 2016, a total of 57 patients, who were admitted into Gunma university hospital with UTI, were enrolled in this study. Seven patients were excluded from this study due to data unavailability. UTI was diagnosed by a urologist based on urinary sediment ( $\geq 5$ leucocytes/high power field) and symptoms (fever and/or micturition pain and/or flank pain). Patient age, sex, medical history, oral medicine, blood pressure, body temperature, heart rate, respiratory rate, urine and blood culture results, surgical procedure for UTI after admission, causative diseases of UTI, presepsin, PCT, CRP, white blood cell (WBC), Aspartate transaminase (ALT), Alanine transaminase (AST), $y$-glutamyl transpeptidase ( $\mathrm{YGPT}$ ) and Creatinine (Cr) were collected. Vital signs and blood data were evaluated at enrollment, and on the 3rd and 5th day after admission. This study was approved by the institutional review board of Gunma University Hospital (No.1650).

\section{Assessment of systemic inflammatory response syndrome (SIRS) and septic shock}

The diagnosis of SIRS and septic shock were made according to the criteria set by the American College of Chest Physicians/Society of Critical Care Medicine (ACCP/SCCM) [10].

\section{Outcomes}

Three outcome variables: SIRS on the enrollment day, septic shock on the enrollment day, and SIRS on the 5th day after admission were evaluated by dividing the participants into two groups for each of these variables; with $(n=39)$ or without $(n=11)$ SIRS on the enrollment day, with $(n=11)$ or without $(n=39)$ septic shock on the enrollment day, and with $(n=7)$ or without $(n=43)$ SIRS on the 5th day after admission, respectively. 


\section{Statistical Analysis}

Mann-Whitney U-test was used for the continuous variables (age, CRP, presepsin, PCT, ALT, AST, YGPT and $\mathrm{Cr}$ ). We estimated the independence by the chi-squared test or Fisher's exact test for categorical variables (sex, placement of urinary catheter, urological cancer, urinary calculi, diabetes mellitus and internal use of steroid). Independent predictors were evaluated using logistic regression analysis. The predictive accuracy of presepsin, PCT, CRP and WBC for septic shock or SIRS was evaluated by the area under the curve (AUC) of a receiver operating characteristics (ROC) analysis. The Youden's index (sensitivity + specificity - 1) was used to calculate optimal cutoff values of presepsin. P values $\leq 0.05$ were considered evidence of a significant difference. SPSS Statistics Ver. 25 (IBM Corp. IL, USA) was used for statistical analysis.

\section{Results}

\section{Patients Characteristic}

Table 1 shows the clinical characteristics of the 50 patients. On the enrollment day, septic shock was detected in $22 \%(n=11)$ and SIRS in $78 \%(n=39)$ of patients. The mean age was 66.5 years, and 33 patients (66\%) were male and 17 (34\%) were female. Bacterial growth in urine and blood cultures were positive in $90 \%(n=45)$ and $48 \%(n=24)$ of samples. There were $48 \%(n=24), 30 \%(n=15), 24 \%(n=12), 18 \%$ $(n=9), 56 \%(n=28)$ and $18 \%(n=9)$ with placement of urinary catheter, urological cancer, urinary calculi, diabetes mellitus, surgical procedure after admission and internal use of steroid, respectively.

\section{Prediction of SIRS on the enrollment day}

The overall median baseline presepsin, PCT, and CRP levels were 483 pg/mL, 0.87 ng/mL, and 10.45 $\mathrm{mg} / \mathrm{L}$, respectively, with no significant difference between SIRS and non-SIRS groups (supplemental Table $1)$."

\section{Prediction of Septic shock on the enrollment day}

The median presepsin level (pg/mL) was significantly higher in the septic shock group (1380 vs. 399 , $\mathrm{p}<0.001)$. The PCT and CRP levels were not significantly different between septic shock and non-septic shock groups. Other blood investigations that were significantly higher in the septic group included: AST $(p=0.003), \operatorname{ALT}(p=0.049)$, yGTP $(p=0.002$ and $\mathrm{Cr}(p=0.02)$, respectively (Table 1a). Logistic regression analysis to evaluate factors associated with septic shock on enrollment day is shown in Table 1b. Factors associated with septic shock on univariate analysis included presepsin ( $\geq 500 \mathrm{pg} / \mathrm{mL}), \mathrm{PCT}(\geq 2$ $\mathrm{ng} / \mathrm{ml})$, AST $(\geq 34 \mathrm{U} / \mathrm{L})$ and YGTP $(\geq 47 \mathrm{U} / \mathrm{L})$. Only presepsin level retained significance after controlling for confounders in multivariate logistic regression analysis (Table 1b). ROC curve for diagnosing septic shock indicated AUC of 0.881 for presepsin, which is larger than other markers (Fig.1). The Cutoff level of presepsin with the optimum diagnostic efficiency by the ROC curves were $492 \mathrm{ng} / \mathrm{ml}$, which was broadly similar to clinical cut off values $(500 \mathrm{pg} / \mathrm{mL})$. 


\section{Prediction of SIRS on the 5th day after admission}

The median presepsin level $(\mathrm{pg} / \mathrm{mL})$ was significantly higher in SIRS on the 5th day after admission group (day $1 ; 1167$ vs. $419, p<0.001$, day3; 633 vs. $311, p=0.027$ ). The PCT (day $1 ; 73.1$ vs. $0.55, p=0.003$, day3; 20.34 vs. $1.35, p=0.005$ )) and CRP (day $1 ; 25.63$ vs. $8.23, p=0.007$, day3; 25.58 vs. $10.71, p<0.001$ ) levels were also significantly different between SIRS and non-SIRS on the 5th day after admission groups. Other blood investigations that were significantly higher in SIRS on the 5th day after admission group included: day1/AST (34 vs. $24, \mathrm{P}=0.013)$, day $1 / \mathrm{Cr}(2.3$ vs. $1.05, \mathrm{p}=0.007)$, day $1 / \mathrm{WBC}$ (18200 vs. $13600, p=0.009$ ) and day3/WBC (11900 vs. $8400, p=0.021$ ) (table $2 a)$. The ratio of positive blood culture $(86 \%$ vs. $42 \%, p=0.039)$ and urinary calculi $(57 \%$ vs. $19 \%, p=0.048)$ significantly differed between SIRS and non-SIRS on the 5th day after admission groups. Logistic regression analysis to evaluate factors associated with SIRS on the 5th day after admission is shown in Table 2b. Factors associated with SIRS on the 5th day after admission in univariate analysis included day $1 /$ presepsin ( $\geq 500 \mathrm{pg} / \mathrm{mL}$ ), day1/PCT ( $\geq 2 \mathrm{ng} / \mathrm{ml}$ ) and urinary calculi. Only day1/PCT level retained significance after controlling for confounders in multivariate logistic regression analysis (Table 2b). ROC curve in patients with definitive prediction of SIRS on the 5th day after admission indicated an AUC at 0.837 for PCT, which is larger than other markers (Fig.1). Concerning presepsin, the cutoff level with the optimum diagnostic efficiency by the ROC curves were $492 \mathrm{ng} / \mathrm{ml}$, which was broadly similar to clinical cut off values ( $500 \mathrm{pg} / \mathrm{mL}$ ).

\section{Discussion}

In this study, elevated presepsin on admission was an independent risk factor for septic shock, while elevated PCT on admission was an independently associated with SIRS on the 5th day after admission for patients admitted with UTI. Presepsin and PCT have the different origin [3-5]. These results support our hypothesis that presepsin is a useful marker for detecting severe sepsis from UTI. On the other hand, PCT can predict therapeutic courses in UTI better than presepsin.

Presepsin is one of the biomarkers which increases after bacterial infections [11]. The levels are increased in acute pyelonephritis patients with bacteremia [12] and elevation of presepsin levels before treatment might predict the development of sepsis in patients with obstructive acute pyelonephritis [13]. In this study, we evaluated the patients who needed hospitalization due to not only pyelonephritis but also prostatitis, and elevation of presepsin levels on the enrollment day was a predictor of septic shock Therefore, it seems that presepsin is useful for detecting severe urosepsis which need vasopressor therapy.

Sever sepsis and septic shock are fatal, with mortality rates of $28.3 \%-41.1 \%$ [14]. Clinically, it is very useful to predict septic shock at the time of admission. It is, therefore, essential that biomarkers increase immediately after infections and have a high sensitivity for sepsis. Presepsin levels have been shown to increase within 2 hours or later together with blood bacterial counts, and peak at 3 hours [6]. On the other hand, elevated PCT and CRP levels are detected within 3-6 hours and 6 hours, and peak at 6-8 hours and 36-50 hours, respectively $[15,16]$. It has also been reported that patients with severe sepsis have 
significantly higher presepsin levels than those with sepsis, local infection or SIRS [17]. In this study, elevation of presepsin levels on the enrollment day was a predictor of septic shock, but not of SIRS on the day of enrollment. These results suggest that presepsin may be used to identify patients at increased risk of more severe infections at early stages.

One important characteristics of biomarkers is the prognostic value. Presepsin levels on day 1 were reported to be correlated with 60-day in-hospital mortality in patients with sepsis, severe sepsis or septic shock [18], a longer intensive-care unit stay, and a lower degree of resolution of the primary infection [8,9]. Mortality is one of the prognostic variables. Since there were no mortalities in this current study, we used presence or absence of SIRS on day 5 for prognosis. In this study, the levels of presepsin on day 1 was significantly higher in SIRS on day 5 groups than non-SIRS on day 5 groups, but the levels of PCT on day 1 was only picked up as a predictor of SIRS on day 5 by multivariate logistic regression analysis. Concerning PCT, the AUC for PCT to predict 30-day mortality in febrile UTI was reported to be 0.71 (95\% Cl: 0.56-0.85) [19]. There are few reports about the comparison of presepsin with PCT for evaluating the prognostic value in UTI. Further researches which include a lot of more sever patients of urosepsis than this study are needed to study the availability of each biomarkers to predict treatment outcomes.

This study had some limitations. First, since 2016, sepsis has been defined using the Sequential (SepsisRelated) Organ Failure Assessment (SOFA) [20]. This study began in 2014, and we did not check conscious level which is a requirement for SOFA scoring. Therefore, instead of SOFA, the SIRS criteria [10] was used for defining sepsis and septic shock. Second, we used a single-center design with a small sample size. Third, we did not consider renal function in setting the reference values of presepsin and PCT. The levels of presepsin and PCT have been reported to be affected by renal function $[21,22]$. It would be ideal to adjust the reference values depending on renal function. However, these adjustments are yet to be clarified.

\section{Conclusions}

This study showed that, in UTI, presepsin may be a good marker for diagnosis of severe patients who need vasopressor therapy at the data of admission, and PCT may be a good marker for predicting hardto-treat cases.

\section{Abbreviations}

ALT: Aspartate transaminase; AST: Alanine transaminase; AUC: The area under the curve; Cr: Creatinine; CRP: C-reactive protein; үGPT: $\gamma$-glutamyl transpeptidase; PCT: Procalcitonin; ROC: A receiver operating characteristics; SIRS: Systemic inflammatory response syndrome; SOFA: the Sequential Organ Failure Assessment; UTI: Urinary tract infections; WBC: White blood cell

\section{Declarations}




\section{Authors' contributions}

YSe perfomed project development, data collection, data analysis and manuscript writing. KK contributed to project development and manuscript editing. DO, HN, YM, TS, SA, MN, HK, HM and YSh contributed to data collection. MM contributed to data analysis. KS contributed to project developments. All authors read and approved the final manuscript.

\section{Funding}

No funding sources.

\section{Availability of data and material}

The datasets generated during the current study are not publicly available due to ethical restrictions.

\section{Ethical approval and consent to participate}

The current study was approved by the Ethical Committee of Gunma University (approval No. 1650), and written consent was obtained from all of the enrolled patients to use their tissues. It was performed in accordance with the principles of the Declaration of Helsinki.

\section{Consent for publication}

Not applicable.

\section{Competing interests}

The authors declare that they have no competing interests.

\section{Acknowledgments}

We thank Ms. Atsuko Oyama, and Ms. Rie Suzuki for their technical assistance.

\section{References}

1. Angus DC, Linde-Zwirble WT, Lidicker J, Clermont G, Carcillo J, Pinsky MR. Epidemiology of severe sepsis in the United States: analysis of incidence, outcome, and associated costs of care. Crit Care Med. 2001;29:1303-10.

2. Levy MM, Artigas A, Phillips GS, Rhodes A, Beale R, Osborn T, et al. Outcomes of the Surviving Sepsis Campaign in intensive care units in the USA and Europe: a prospective cohort study. Lancet Infect Dis. 2012;12:919-24.

3. Brunkhorst FM, Heinz U, Forycki ZF. Kinetics of procalcitonin in iatrogenic sepsis. Intensive Care Med. 1998;24:888-9. 
4. Dandona P, Nix D, Wilson MF, Aljada A, Love J, Assicot M, et al. Procalcitonin increase after endotoxin injection in normal subjects. J Clin Endocrinol Metab. 1994;79:1605-8.

5. Yaegashi Y, Shirakawa K, Sato N, Suzuki Y, Kojika M, Imai S, et al. Evaluation of a newly identified soluble CD14 subtype as a marker for sepsis. J Infect Chemother. 2005;11:234-8.

6. Nakamura M, Takeuchi T, Naito K, Shirakawa K, Hosaka Y, Yamasaki F, et al. Early elevation of plasma soluble CD14 subtype, a novel biomarker for sepsis, in a rabbit cecal ligation and puncture model. Crit Care. 2008;12(Suppl 2): 194.

7. Zou Q, Wen W, Zhang XC. Presepsin as a Novel Sepsis Biomarker. World J Emerg Med. 2014;5:16-9.

8. Masson S, Caironi P, Fanizza C, Thomae R, Bernasconi R, Noto A, et al. Circulating presepsin (soluble CD14 subtype) as a marker of host response in patients with severe sepsis or septic shock: data from the multicenter, randomized ALBIOS trial. Intensive Care Med. 2015;41:12-20.

9. Kim H, Hur M, Moon HW, Yun YM, Di Somma S. Multi-marker approach using procalcitonin, presepsin, galectin-3, and soluble suppression of tumorigenicity 2 for the prediction of mortality in sepsis. Ann Intensive Care. 2017;7:27.

10. Bone RC, Balk RA, Cerra FB, Dellinger RP, Fein AM, Knaus WA, et al. Definitions for Sepsis and Organ Failure and Guidelines for the Use of Innovative Therapies in Sepsis. The ACCP/SCCM Consensus Conference Committee. American College of Chest Physicians/Society of Critical Care Medicine. Chest. 1992;101:1644-55.

11. Memar MY, Baghi HB. Presepsin: A promising biomarker for the detection of bacterial infections. Biomed Pharmacother. 2019;111:649-56.

12. Claessens Y-E, Trabattoni E, Grabar S, Quinguis L, Sahakian G, Anselmo M, et al. Plasmatic Presepsin (sCD14-ST) Concentrations in Acute Pyelonephritis in Adult Patients. Clin Chim Acta. 2017;464:1828.

13. Tambo M, Taguchi S, Nakamura Y, Okegawa T, Fukuhara H. Presepsin and Procalcitonin as Predictors of Sepsis Based on the New Sepsis-3 Definitions in Obstructive Acute Pyelonephritis. BMC Urol. 2020;20:23.

14. Levy MM, Artigas A, Phillips GS, Rhodes A, Beale R, Osborn T, et al. Outcomes of the Surviving Sepsis Campaign in intensive care units in the USA and Europe: a prospective cohort study. Lancet Infect Dis. 2012;12:919-24.

15. Maruna P, Nedelníková K, Gürlich R. Physiology and Genetics of Procalcitonin. Physiol Res 2000; 49(Suppl 1):57-61.

16. Lelubre C, Anselin S, Boudjeltia KZ, Biston P, Piagnerelli M. Interpretation of C-reactive Protein Concentrations in Critically III Patients. Biomed Res Int. 2013;2013:124021.

17. Shozushima T, Takahashi G, Matsumoto N, Kojika M, Okamura Y, Endo S. Usefulness of presepsin (sCD14-ST) measurements as a marker for the diagnosis and severity of sepsis that satisfied diagnostic criteria of systemic inflammatory response syndrome. J Infect Chemother. 2011;17:764-9.

18. Ulla M, Pizzolato E, Lucchiari M, Loiacono M, Soardo F, Forno D, et al. Diagnostic and prognostic value of presepsin in the management of sepsis in the emergency department: a multicenter 
prospective study. Crit Care. 2013;17:R168.

19. Starre WE, Zunder SM, Vollaard AM, Nieuwkoop CV, Stalenhoef JE, Delfos NM, et al. Prognostic Value of Pro-Adrenomedullin, Procalcitonin and C-reactive Protein in Predicting Outcome of Febrile Urinary Tract Infection. Clin Microbiol Infect. 2014;20:1048-54.

20. Singer M, Deutschman CS, Seymour CW, Shankar-Hari M, Annane D, Bauer M, et al. The Third International Consensus Definitions for Sepsis and Septic Shock (Sepsis-3). JAMA. 2016;315:801-10.

21. Nakamura $Y$, Ishikura H, Nishida T, Kawano Y, Yuge R, Ichiki R, et al. Usefulness of presepsin in the diagnosis of sepsis in patients with or without acute kidney injury. BMC Anesthesiol. 2014;14:88.

22. Amour J, Birenbaum A, Langeron $O$, Le Manach Y, Bertrand M, Coriat $P$, et al. Influence of renal dysfunction on the accuracy of procalcitonin for the diagnosis of postoperative infection after vascular surgery. Crit Care Med. 2008;36:1147-54.

\section{Tables}

Table 1a. Characteristics of Patients with or without septic shock on the enrollment day

\begin{tabular}{|c|c|c|c|c|}
\hline & Total & $\begin{array}{l}\text { Septic shock } \\
\text { group }\end{array}$ & $\begin{array}{l}\text { Non-septic shock } \\
\text { group }\end{array}$ & \\
\hline Variable & $\mathrm{N}=50$ & $\mathrm{~N}=11$ & $\mathrm{~N}=39$ & p-value \\
\hline Age (years) & $\begin{array}{l}66.5[60.3- \\
75.5]]\end{array}$ & $64[49-70]$ & $68[61-78]$ & 0.055 \\
\hline White blood cell (/mm】) & $\begin{array}{l}13600[10375- \\
18000]\end{array}$ & $\begin{array}{l}13600[9900- \\
25600]\end{array}$ & $\begin{array}{l}13600[10400- \\
16600]\end{array}$ & 0.788 \\
\hline C-reactive protein (mg/L) & $\begin{array}{l}10.45[4.26- \\
23.06]\end{array}$ & $11.47[6.41-$ & $10.2[4.21-22.37]$ & 0.406 \\
\hline Presepsin $(\mathrm{pg} / \mathrm{mL})$ & $483[277-1130]$ & $1380[924-$ & 399 [254-707] & $<0.001$ \\
\hline Procalcitonin (ng/mL) & $0.87[0.20-17.1]$ & $25.06[0.42-$ & $0.66[0.14-2.06]$ & 0.056 \\
\hline $\begin{array}{l}\text { Aspartate } \\
\text { transaminase (U/L) }\end{array}$ & $24.5[19.8-35.3]$ & $44[24-133]$ & 24 [18-29] & 0.003 \\
\hline $\begin{array}{l}\text { Alanine } \\
\text { transaminase (U/L) }\end{array}$ & $17[11.8-30.0]$ & 19 [15-52] & $17[11-24]$ & 0.049 \\
\hline $\begin{array}{l}\text {-glutamyl } \\
\text { transpeptidase }(\mathrm{U} / \mathrm{L})\end{array}$ & $31[21.0-53.3]$ & 70 [43-74] & 26 [20-43] & 0.002 \\
\hline Creatinine $(\mathrm{mg} / \mathrm{dL})$ & 1.24 [0.87-1.99] & $\begin{array}{l}1.85[1.19- \\
3.86]\end{array}$ & $1.05[0.85-1.84]$ & 0.020 \\
\hline sex (male/female) & $33 / 17$ & $8 / 3$ & $25 / 14$ & 0.440 \\
\hline $\begin{array}{l}\text { placement of urinary } \\
\text { catheter }(\mathrm{Y} / \mathrm{N})\end{array}$ & $24 / 26$ & $6 / 5$ & $18 / 21$ & 0.623 \\
\hline urological cancer $(\mathrm{Y} / \mathrm{N})$ & $15 / 35$ & $1 / 10$ & $14 / 25$ & 0.085 \\
\hline urinary calculi $(\mathrm{Y} / \mathrm{N})$ & $12 / 38$ & $4 / 7$ & $8 / 31$ & 0.240 \\
\hline $\begin{array}{l}\mathrm{DM}(\mathrm{Y} / \mathrm{N}) \\
\text { internal use of steroid } \\
(\mathrm{Y} / \mathrm{N})\end{array}$ & $\begin{array}{l}9 / 41 \\
9 / 41\end{array}$ & $\begin{array}{l}3 / 8 \\
3 / 8\end{array}$ & $\begin{array}{l}6 / 33 \\
6 / 33\end{array}$ & $\begin{array}{l}0.308 \\
0.308\end{array}$ \\
\hline
\end{tabular}


Values are expressed as number or median [interquartile range, IQR]. DM; diabetes mellitus, Y; yes, N; No,

Table $1 \mathrm{~b}$. Prediction of septic shock on the enrollment day by logistic regression analysis

\begin{tabular}{|c|c|c|c|c|c|c|}
\hline \multirow[b]{2}{*}{ Variable } & \multicolumn{3}{|c|}{ Univariate analysis } & \multicolumn{3}{|c|}{ Multivariable analysis } \\
\hline & $\begin{array}{l}\mathrm{P}- \\
\text { value }\end{array}$ & HR & $95 \% \mathrm{CI}$ & $\begin{array}{l}\mathrm{P}- \\
\text { value }\end{array}$ & HR & $95 \% \mathrm{CI}$ \\
\hline $\begin{array}{l}\text { sex (male vs female) } \\
\text { WBC (4000-12 } 000 \text { vs other) }\end{array}$ & 0.595 & & & & & \\
\hline $\begin{array}{l}\text { WBC }(4,000-12,000 \text { vs other }) \\
\text { CRP }(>0.5 \text { ys }<0.5)\end{array}$ & $\begin{array}{l}0.497 \\
0360\end{array}$ & & & & & \\
\hline $\mathrm{CRP}(\geq 10$ vs $<10)$ & 0.848 & & & & & \\
\hline Presepsin $(\geq 500$ vs $<500)$ & 0.007 & 20.000 & $2.305-$ & 0.029 & 12.157 & $1.298-$ \\
\hline PCT $(\geq 0.05$ vs $<0.05)$ & 0.630 & & & & & \\
\hline $\mathrm{PCT}(\geq 2$ vs $<2)$ & 0.025 & 5.075 & $1.223-$ & 0.673 & & \\
\hline AST $(\geq 34$ vs $<34)$ & 0.006 & 8.000 & $1.829-$ & 0.375 & & \\
\hline ALT $(\geq 28$ vs $<28$ ) & 0.105 & & & & & \\
\hline$\gamma \mathrm{GPT}(\geq 47$ vs $<47)$ & 0.005 & 8.889 & $1.941-$ & 0.081 & & \\
\hline $\begin{array}{l}\text { Cr (male; } \geq 1.07 \text { vs }<1.07 \text {, } \\
\text { female; } \geq 0.79 \text { vs }<0.79 \text { ) }\end{array}$ & 0.095 & & & & & \\
\hline placement of urinary catheter & 0.624 & & & & & \\
\hline urological cancer (Y vs $\mathrm{N})$ & 0.118 & & & & & \\
\hline urinary calculi (Y vs N) & 0.284 & & & & & \\
\hline DM (Y vs N) & 0.371 & & & & & \\
\hline internal use of steroid ( $\mathrm{Y}$ vs $\mathrm{N}$ ) & 0.371 & & & & & \\
\hline
\end{tabular}


WBC; white blood cell, CRP; C-reactive protein, PCT; procalcitonin, AST; Aspartate transaminase, ALT; Alanine transaminase, $\gamma \mathrm{GTP} ; \gamma$-glutamyl transpeptidase, $\mathrm{Cr}$; creatinine, DM; diabetes mellitus, Y; yes, N; No,

Table2a. Characteristics of Patients with or without SIRS on the 5th day

\begin{tabular}{|c|c|c|c|}
\hline & SIRS group & Non-SIRS group & \\
\hline Variable & $\mathrm{N}=7$ & $\mathrm{~N}=43$ & p-value \\
\hline Age (years) & $64[54-68]$ & $68[61-77]$ & 0.126 \\
\hline $\begin{array}{l}\text { day1/White blood cell } \\
\left(/ \mathrm{mm}^{3}\right)\end{array}$ & $\begin{array}{l}18200[17200- \\
24900]\end{array}$ & $13600[9900-16000]$ & 0.009 \\
\hline $\begin{array}{l}\text { day1/C-reactive protein } \\
(\mathrm{mg} / \mathrm{L})\end{array}$ & $25.63[9.58-31.38]$ & $8.23[4.1-16.6]$ & 0.007 \\
\hline day1/Presepsin (pg/mL) & 1167 [878-5129] & $419[277-922]$ & 0.006 \\
\hline day1/Procalcitonin (ng/mL) & 73.1 [25.06-103.73] & $0.55[0.14-2.06]$ & 0.003 \\
\hline $\begin{array}{l}\text { day1/Aspartate transaminase } \\
\text { (U/L) }\end{array}$ & $34[28-126]$ & $24[18-33]$ & 0.013 \\
\hline $\begin{array}{l}\text { day1/Alanine transaminase } \\
(\mathrm{U} / \mathrm{L})\end{array}$ & $23[18-52]$ & $16[11-25]$ & 0.056 \\
\hline $\begin{array}{l}\text { day } 1 / \mathrm{Y} \text {-glutamyl } \\
\text { transpeptidase }(\mathrm{U} / \mathrm{L})\end{array}$ & $48[38-72]$ & $28[21-51]$ & 0.133 \\
\hline day $1 /$ Creatinine $(\mathrm{mg} / \mathrm{dL})$ & $2.30[1.72-2.71]$ & $1.05[0.85-1.84]$ & 0.007 \\
\hline $\begin{array}{l}\text { day3/White blood cell } \\
\left(/ \mathrm{mm}^{3}\right)\end{array}$ & 11900 [9400-20100] & 8400 [5900-10400] & 0.021 \\
\hline $\begin{array}{l}\text { day3/C-reactive protein } \\
(\mathrm{mg} / \mathrm{L})\end{array}$ & $25.58[16.47-34.54]$ & $10.71[6.55-15.40]$ & $<0.001$ \\
\hline day3/Presepsin $(\mathrm{pg} / \mathrm{mL})$ & $633[464-1360]$ & 311 [196-695] & 0.027 \\
\hline day3/Procalcitonin ( $\mathrm{ng} / \mathrm{mL}$ ) & $20.34[14.23-32.27]$ & $1.35[0.30-15.09]$ & 0.005 \\
\hline sex (male/female) & $4 / 3$ & $29 / 14$ & 0.446 \\
\hline urinary culture $(\mathrm{P} / \mathrm{N})$ & $7 / 0$ & $38 / 5$ & 0.454 \\
\hline blood culture $(\mathrm{P} / \mathrm{N})$ & $6 / 1$ & $18 / 25$ & 0.039 \\
\hline $\begin{array}{l}\text { placement of urinary } \\
\text { catheter }(\mathrm{Y} / \mathrm{N})\end{array}$ & $2 / 5$ & $22 / 21$ & 0.244 \\
\hline urological cancer $(\mathrm{Y} / \mathrm{N})$ & $1 / 6$ & $14 / 29$ & 0.311 \\
\hline urinary calculi $(\mathrm{Y} / \mathrm{N})$ & $4 / 3$ & $8 / 35$ & 0.048 \\
\hline $\mathrm{DM}(\mathrm{Y} / \mathrm{N})$ & $1 / 6$ & $8 / 35$ & 0.630 \\
\hline surgical procedure $(\mathrm{Y} / \mathrm{N})$ & $6 / 1$ & $22 / 21$ & 0.095 \\
\hline internal use of steroid $(\mathrm{Y} / \mathrm{N})$ & $2 / 5$ & $7 / 36$ & 0.370 \\
\hline
\end{tabular}

Values are expressed as number or median [interquartile range, IQR].

DM; diabetes mellitus, P; positive, N; No, Y; yes 
Table $2 \mathrm{~b}$. Prediction of SIRS on the 5 th day by logistic regression analysis

\begin{tabular}{|c|c|c|c|c|c|c|}
\hline \multirow[b]{2}{*}{ Variable } & \multicolumn{3}{|c|}{ Univariate analysis } & \multicolumn{3}{|c|}{ Multivariable analysis } \\
\hline & P-value & $\mathrm{HR}$ & $95 \% \mathrm{Cl}$ & $\begin{array}{l}\text { P- } \\
\text { value }\end{array}$ & $\mathrm{HR}$ & $95 \% \mathrm{Cl}$ \\
\hline $\begin{array}{l}\text { day } 1 / \text { WBC } \\
(4,000-12,000 \text { or other })\end{array}$ & 0.19 & & & & & \\
\hline day $1 /$ CRP $(\geq 10$ or $<10)$ & 0.280 & & & & & \\
\hline $\begin{array}{l}\text { day1/Presepsin }(\geq 500 \text { or }< \\
500)\end{array}$ & 0.049 & $\begin{array}{l}9.17 \\
6\end{array}$ & $\begin{array}{l}1.013- \\
83.108\end{array}$ & 0.366 & & \\
\hline day1/PCT $(\geq 2$ or $<2$ ) & 0.012 & $\begin{array}{l}17.4 \\
55\end{array}$ & $\begin{array}{l}1.886- \\
161.528\end{array}$ & 0.012 & $\begin{array}{l}17.4 \\
55\end{array}$ & $\begin{array}{l}1.886- \\
161.528\end{array}$ \\
\hline day1/AST $(\geq 34$ or $<34$ ) & 0.079 & & & & & \\
\hline day1/ALT ( $\geq 28$ or $<28$ ) & 0.283 & & & & & \\
\hline $\begin{array}{l}\text { day1//GPT ( } \geq 47 \text { or }<47 \text { ) } \\
\text { day1/Cr (male; } \geq 1.07 \text { or }<\end{array}$ & 0.177 & & & & & \\
\hline $\begin{array}{l}1.07 \text {, } \\
\text { female; } \geq 0.79 \text { or }<0.79 \text { ) }\end{array}$ & 0.998 & & & & & \\
\hline $\begin{array}{l}\text { day3/WBC } \\
(4,000-12,000 \text { or other })\end{array}$ & 0.120 & & & & & \\
\hline day3/CRP $(\geq 10$ or $<10)$ & 0.998 & & & & & \\
\hline $\begin{array}{l}\text { day3/Presepsin }(\geq 500 \text { or }< \\
500)\end{array}$ & 0.067 & & & & & \\
\hline day3/PCT $(\geq 2$ or $<2)$ & 0.998 & & & & & \\
\hline sex (male or female) & 0.596 & & & & & \\
\hline urinary culture ( $\mathrm{P}$ vs $\mathrm{N}$ ) & 0.999 & & & & & \\
\hline $\begin{array}{l}\text { blood culture (P vs N) } \\
\text { placement of urinary }\end{array}$ & 0.059 & & & & & \\
\hline $\begin{array}{l}\text { catheter } \\
\text { (Y vs N) }\end{array}$ & 0.280 & & & & & \\
\hline urological cancer (Y vs N) & 0.346 & & & & & \\
\hline urinary calculi ( $\mathrm{Y}$ vs $\mathrm{N}$ ) & 0.040 & $\begin{array}{l}5.83 \\
3\end{array}$ & $\begin{array}{l}1.084- \\
31.377\end{array}$ & 0.182 & & \\
\hline $\mathrm{DM}(\mathrm{Y}$ vs $\mathrm{N})$ & 0.783 & & & & & \\
\hline surgical procedure ( $\mathrm{Y}$ vs $\mathrm{N}$ ) & 0.120 & & & & & \\
\hline $\begin{array}{l}\text { internal use of steroid ( } \mathrm{Y} \text { vs } \\
N \text { ) }\end{array}$ & 0.439 & & & & & \\
\hline
\end{tabular}

WBC; white blood cell, CRP; C-reactive protein, PCT; procalcitonin, AST; Aspartate transaminase, ALT; Alanine transaminase, $\gamma$ GTP; $\gamma$-glutamyl transpeptidase, $\mathrm{Cr}$; creatin ine,

DM; diabetes mellitus, $\mathrm{P}$; positive, N; No, $Y$; yes

\section{Figures}


$<$ Septic shock on the enrollment day>

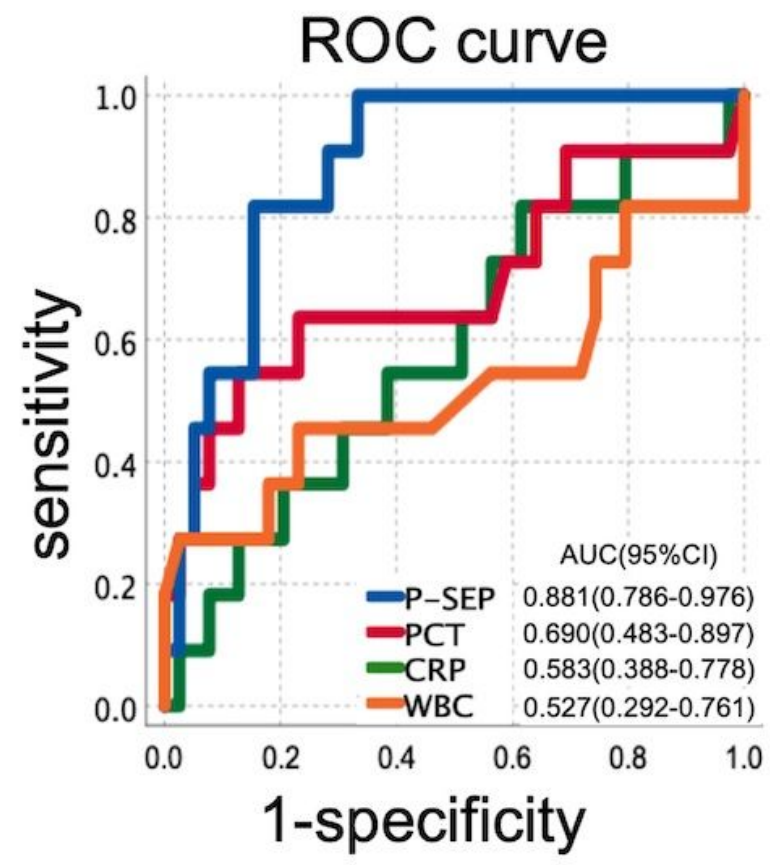

$<$ SIRS on the 5th day after admission $>$

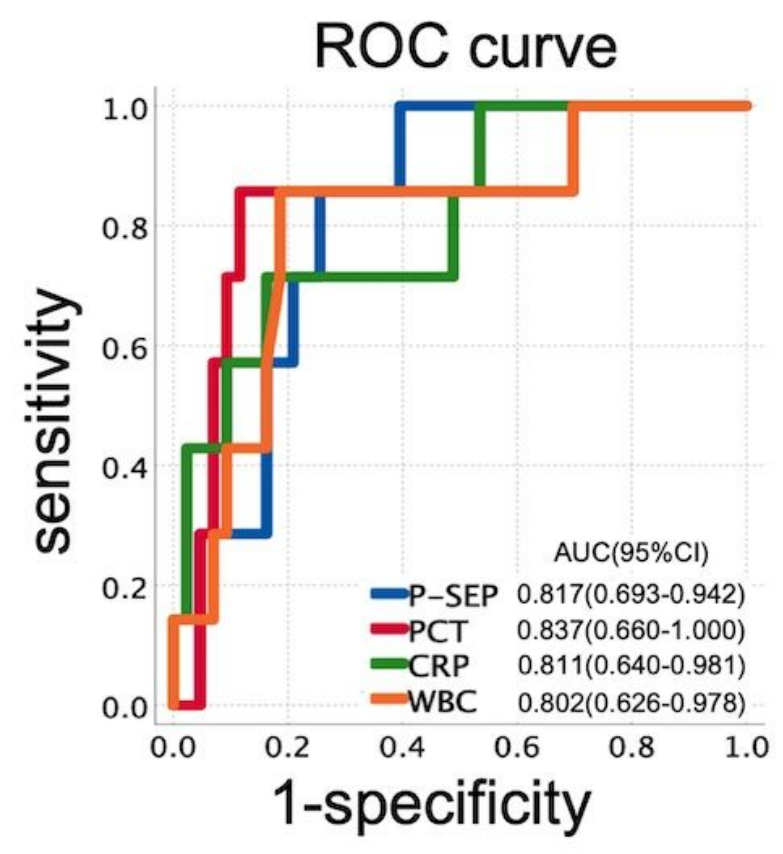

Figure 1

ROC curve for presepsin, procalcitonin, CRP and WBC in patients with definitive prediction of septic shock on the enrollment day and SIRS on the 5th day after admission. P-SEP; presepsin, PCT; procalcitonin, CRP; C-reactive protein, WBC; white blood cell

\section{Supplementary Files}

This is a list of supplementary files associated with this preprint. Click to download.

- supplementalTable1.docx 